\section{REVIEW OF FILTER STRIP PERFORMANCE AND FUNCTION FOR IMPROVING WATER QUALITY FROM AGRICULTURAL LANDS}

\author{
K. R. Douglas-Mankin, M. J. Helmers, R. D. Harmel
}

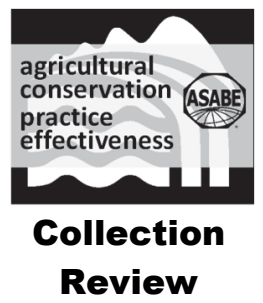

\title{
HighLIGHTS
}

- Filter strip processes for water pollutant reductions were quantified from 74 studies with almost 300 data points.

- Regression was significant versus width (sediment, N, P), area ratio (sediment, atrazine), and $K_{s}(\mathrm{~N}, \mathrm{P}$, atrazine, alachlor).

- This review discusses ten functional factors affecting FS efficiency as well as FS monitoring recommendations.

- Cost-effectiveness was assessed and varies considerably by influent load and treatment effectiveness.

\begin{abstract}
Filter strips (FSs) are edge-of-field conservation practices commonly implemented to reduce flux of sediment, nutrients, and other constituents from agricultural fields. While various aspects of FS effectiveness have been reviewed, this study provides a comprehensive summary of FS efficiency data for sediment, nutrients, pesticides, and pathogens as part of a special collection focused on agricultural conservation practices. This analysis also fills an important gap by assessing performance-based FS costs and cost-effectiveness. Data from 74 U.S. and international studies with 294 different treatments and 3,050 replications were compiled and analyzed. Results showed that runoff reduction tended to increase with increasing FS width up to about $15 \mathrm{~m}$ and that sediment reduction was significantly related to the ratio of FS area to drainage area and to FS width, with reduction tending to increase with increasing width up to about $20 \mathrm{~m}$. Total P reduction was significantly related to FS soil saturated hydraulic conductivity, and total $N$ reduction was significantly related to both saturated hydraulic conductivity and width. Total P and total N reductions both tended to increase with increasing FS width up to about $20 \mathrm{~m}$ and with increasing FS slope up to about $10 \%$. Annualized FS costs were estimated to range from $\$ 314$ to $\$ 865 \mathrm{ha}^{-1}$ year ${ }^{-1}$ for different FS implementations. A major component of the cost is the opportunity cost of taking land out of production. Costs per unit of sediment retained by FS systems ranged from $\$ 10.3$ to $\$ 18.6 \mathrm{Mg}^{-1}$. A comprehensive assessment of FS cost-effectiveness (cost:benefit) is needed. Monitoring equipment, approaches, and recommendations are discussed, acknowledging the challenges of implementing field-scale FS studies. This information is critical to guide on-farm and programmatic FS decisions and to increase the scientific understanding of this commonly used agricultural conservation practice.
\end{abstract}

Keywords. Best management practice, Buffer strip, Nonpoint-source pollution, Riparian buffer, Vegetated filter strip.

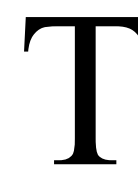

his article is part of a collection that provides comprehensive reviews and evaluations of the performance and cost-effectiveness of selected agricultural conservation practices (ACPs) on pollutant

Submitted for review on 19 June 2020 as manuscript number NRES 14169; approved for publication as an Invited Review Article and as part of the Agricultural Conservation Practice Effectiveness Collection by the Natural Resources \& Environmental Systems Community of ASABE on 19 October 2020.

Mention of company or trade names is for description only and does not imply endorsement by the USDA. The USDA is an equal opportunity provider and employer.

The authors are Kyle R. Douglas-Mankin, Research Leader, USDAARS Water Management and Systems Research Unit, Fort Collins, Colorado; Matthew J. Helmers, Director, Iowa Nutrient Research Center, Iowa State University, Ames, Iowa; R. Daren Harmel, Director, USDAARS Center for Agricultural Resources Research, Fort Collins, Colorado. Corresponding author: Kyle Douglas-Mankin, USDA-ARS, 2150 Center Ave., Building D, Fort Collins, CO 80526; phone: 970-492-7401; e-mail: kyle.douglas-mankin@usda.gov. (sediment, nutrients, pesticides, and fecal indicator organisms) reduction (Yuan et al., 2021).

Vegetative buffers and filter strips (FSs) are commonly used to reduce the water quality and environmental impacts of agricultural production. The USDA Natural Resources Conservation Service (NRCS) has several Conservation Practice Standards that address these edge-of-field practices, as summarized in the National Handbook of Conservation Practices (NRCS, 2017): Filter Strip (Code 393), Riparian Forest Buffer (Code 391), and Riparian Herbaceous Cover (Code 390) (NRCS, 2016). This review focuses on FSs using perennial grasses, but similarity in processes among these practices makes much of the analysis directly applicable to other edge-of-field vegetative buffers.

Filter strips are defined as "a strip or area of herbaceous vegetation that removes contaminants from overland flow" (NRCS, 2016). As prescribed by the Filter Strip Conservation Practice Standard (Code 393), FSs are intended to reduce loadings of suspended sediment, sediment-sorbed contaminants, and dissolved contaminants in runoff entering 
surface waters. Surface inflow is intended to enter the FS uniformly as sheet flow, and the FS slope is intended to be half (or less, and no greater than 5\%) that of the upslope source area. Filter strips are applicable anywhere environmentally sensitive areas need protection from contaminants in agricultural runoff. Filter strips should be established appropriate to local conditions, with stiff-stemmed, high stem density, permanent grass vegetation that is tolerant of herbicides and able to withstand partial burial from sediment deposition.

Considerable research has studied the performance of FSs, as noted in a variety of review articles. Previous review articles tended to focus on a subset of constituents, such as sediment (Liu et al., 2008; Yuan et al., 2009), nutrients (Prosser et al., 2020; Valkama et al., 2019), or pesticides (Krutz et al., 2005; Patzold et al., 2007; Prosser et al., 2020; Reichenberger et al., 2019); on impacts, such as water quality (Helmers et al., 2008) or holistic benefits (Stutter et al., 2019); on design characteristics, such as width (Collins et al., 2009; Lee et al., 2004), FS to upslope drainage area ratio (Dosskey et al., 2011), or time since establishment (Dosskey et al., 2007); or on applications, such as runoff from livestock systems (Koelsch et al., 2006), buffer strips (Barling and Moore, 1994; Lee et al., 2004; Mayer et al., 2005), the E.U. Water Framework Directive (Collins et al., 2009), or U.S. Gulf Hypoxia (Helmers et al., 2008). In contrast, this review article provides an exhaustive summary of FS performance for a broad range of contaminants and fills an important gap by assessing performance-based costs and urging subsequent analysis of overall cost-effectiveness.

The cost of FSs and other buffers is considered "additional" (i.e., farmers will not implement them without payments) $80 \%$ of the time (Claassen et al., 2014; Claassen and Ribaudo, 2016). As such, implementation often requires government incentives. In the U.S., a program implemented in 1997 by the USDA, the National Conservation Buffer Initiative (NCBI), installed 1.95 million $\mathrm{km}$ (1.21 million mi) and 1.76 million ha (4.36 million ac) of conservation buffers in its first five years (Loftus and Kraft, 2003). Survey data from that period indicated that "simply informing farmland owners of the eligibility of their land has the potential to increase willingness for filter strip enrollment" (Loftus and Kraft, 2003). Indicators of increased participation included greater debt, less reliance on farm-generated income (compared to non-farm income), and more regular visits to NRCS offices.

The overall objective of this study is to develop an understanding of FS processes and cost-effectiveness in water pollutant reduction. More detailed objectives are to: (1) compare, integrate, and synthesize results from reviewed studies conducted under different experimental settings and site conditions to obtain a systematic understanding of FS efficacy, (2) obtain general insights from reviewed studies on FS performance-based costs, (3) develop recommendations for FS cost-effectiveness for consideration to inform agency prioritization and program development, and (4) collect or summarize scientific data to support updates of NRCS Conservation Practice Standards and to enhance documentation of FS efficiencies.

\section{Materials ANd Methods}

Data from the published international literature were compiled and analyzed for this study. The focus was on studies presenting edge-of-field FS performance efficiency and costeffectiveness. Detailed data from 74 studies spanning 15 U.S. states, two Canadian provinces, and eleven other countries were summarized. Performance process insights were also noted from many other research and review articles.

Filter strip efficiency was based on mass reduction of constituents; articles presenting only concentration reductions were not included. Constituents included sediment, total phosphorus (TP), dissolved $\mathrm{P}(\mathrm{DP})$, particulate $\mathrm{P}(\mathrm{PP})$, total nitrogen $(\mathrm{TN})$, nitrate $\mathrm{N}\left(\mathrm{NO}_{3}-\mathrm{N}\right)$, ammonium $\mathrm{N}\left(\mathrm{NH}_{4}-\mathrm{N}\right)$, organic $\mathrm{N}(\mathrm{ON})$, total Kjeldahl N (TKN), atrazine (ATR), alachlor (ALA), eight other pesticides (permethrin, chlorpyrifos, cyanazine, diflufenican, metribuzine, deethylatrazine, terbuthylazine, and pendimethalin), and fecal indicator organisms (FIO). Efficiency data from each study were separated by treatment for analysis. Treatment information was recorded, including location, filter width (W, distance in downslope direction), filter slope (S), filter area to upslope drainage area ratio (AR), soil texture, vegetation type, vegetation cover density, rainfall/runoff application method, rainfall intensity, rainfall depth or volume, and number of treatment replications included in the reported efficiency values. Soil texture data were used to estimate saturated hydraulic conductivity $\left(K_{s}\right)$ based on unadjusted estimated values from table 3 of Saxton and Rawls (2006). Data for a total of 294 different treatments and 3,050 replications were compiled (DouglasMankin, 2021). Study treatments with FS areas greater than source areas $(\mathrm{AR}>1)$ were excluded because these larger areas are generally termed vegetative treatment areas and are used to treat runoff from more-acute sources (e.g., animal feeding operations) (Koelsch et al., 2006). All data are available in a supplemental table (Douglas-Mankin, 2021) based on the references listed in the Appendix.

\section{REDUCTION EFFICIENCY RUNOFF}

Runoff reduction averaged 52\% across 198 treatments (range: $-42 \%$ to $100 \%$ ) (table 1). Runoff reduction was significantly related to $\mathrm{W}(\mathrm{p}=0.008)$ but with little explanatory power $\left(r^{2}=0.05\right)$ (table 2). Data from the literature showed that runoff reduction tended to increase with increasing $\mathrm{W}$ up to about $15 \mathrm{~m}$, plateauing at about $70 \%$ reduction (fig. 1a).

\section{SEDIMENT}

Sediment mass reduction averaged $78 \%$ across 198 treatments (range: $-26 \%$ to $100 \%$ ) (table 1). Sediment reduction was significantly related to AR $(\mathrm{p}=0.006)$ and $\mathrm{W}(\mathrm{p}=$ $0.019)$ but with little explanatory power $\left(r^{2}=0.08\right)($ table 2$)$. Data showed that sediment reduction tended to increase with increasing $\mathrm{W}$ up to about $20 \mathrm{~m}$, plateauing at about $80 \%$ to $90 \%$ reduction. (fig. $1 \mathrm{~b}$ ).

\section{PHOSPHORUS}

Total phosphorus (TP) mass reduction averaged 63\% across 119 treatments (range: $-15 \%$ to $100 \%$ ) (table 1 ). 

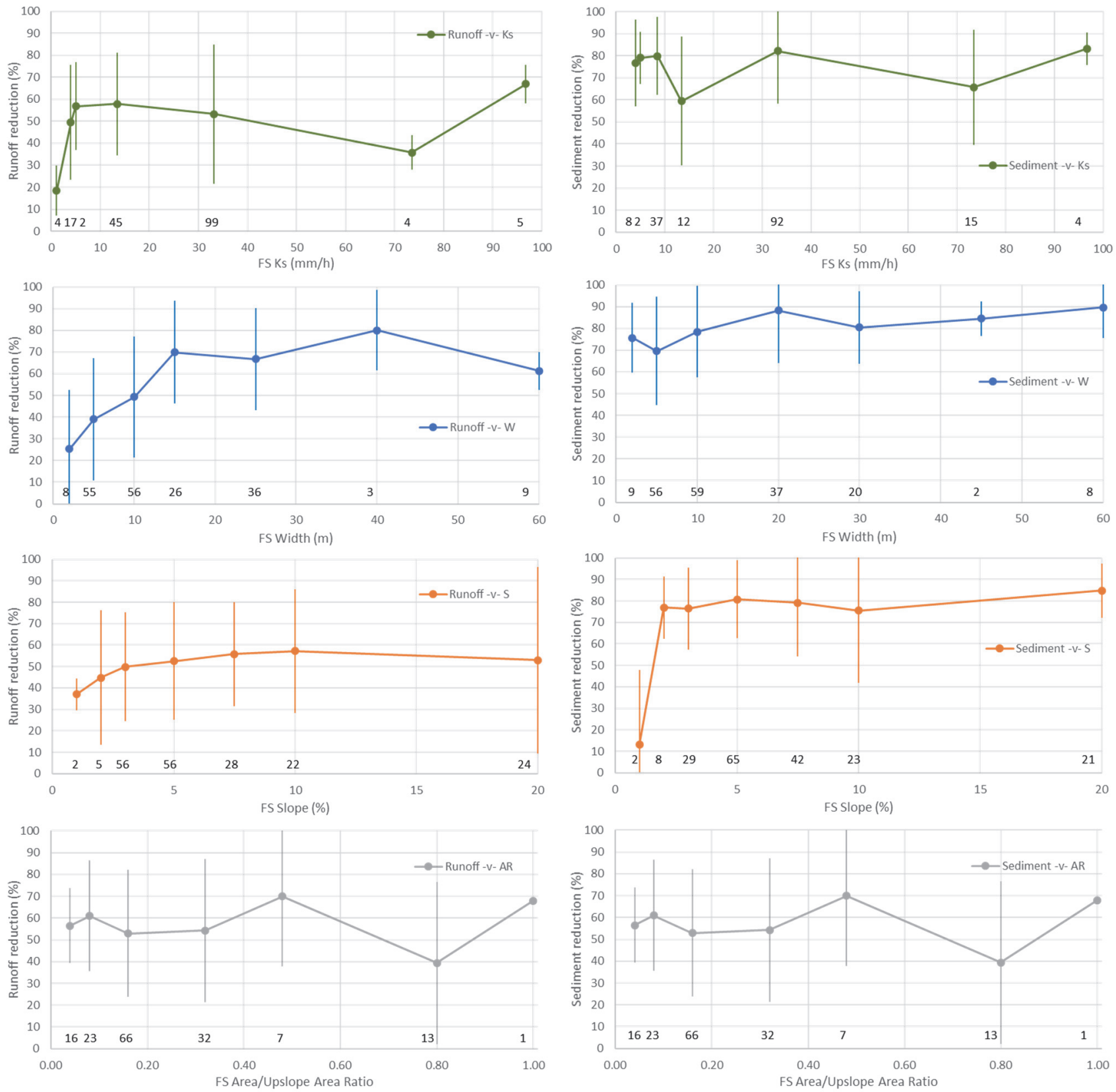

(a)

(b)

Figure 1. Effects of filter strip (FS) soil saturated hydraulic conductivity $\left(K_{s}\right)$, width $(W)$, slope (S), and FS area to upslope area ratio (AR) on mass reductions of (a) runoff and (b) sediment. Data points are means \pm standard deviations of $n$ treatments, with $n$ values shown below.

reduction but that longer or wider filters were needed for $\mathrm{P}$ control and observed no "wash off" or re-entrainment of deposited sediment in subsequent events.

In contrast, several studies found little benefit from increasing W. For example, Lafrance et al. (2013) found that $3 \mathrm{~m}$ grass filters provided similar herbicide reductions as 6 or $9 \mathrm{~m}$ filters. Blanco-Canqui et al. (2004) reported that filter efficiency increased with $\mathrm{W}$, but the first $4 \mathrm{~m}$ reduced $18 \%$ of runoff, $92 \%$ of sediment, and $71 \%$ of nutrients. Tingle et al. (1998) found no difference in reductions of runoff, sediment, or herbicides for FS plots with $\mathrm{W}$ from 0.5 to $4 \mathrm{~m}$ compared to no FS, although they suggested that further study is needed to extend these results to practical scales.
Width has been related to sediment trapping efficiency using a logarithmic regression model $\left(\mathrm{r}^{2}=0.34, n=79\right)$ applied to data from studies included in a review by Liu et al. (2008). The expanded dataset used in this article supported $\mathrm{W}$ as a significant regression variable in explaining reduction efficiency for runoff and three constituents (table 2): runoff as a function of $\mathrm{W}$ alone $\left(\mathrm{p}=0.008, \mathrm{r}^{2}=0.05, n=\right.$ $161)$, sediment $\left(\mathrm{r}^{2}=0.08, n=161\right)$ as a function of $\mathrm{W}(\mathrm{p}=$ $0.019)$ together with $\mathrm{AR}(\mathrm{p}=0.006), \mathrm{TP}\left(\mathrm{r}^{2}=0.34, n=46\right)$ as a function of $\mathrm{W}(\mathrm{p}=0.0006)$ together with $K_{s}(\mathrm{p}=0.045)$, and $\mathrm{TN}\left(\mathrm{r}^{2}=0.19, n=62\right)$ as a function of $\mathrm{W}(\mathrm{p}=0.012)$ together with $K_{s}(\mathrm{p}=0.045)$. A similar general relationship was found between W and runoff (fig. 1a), TP (fig. 2a), and, to a lesser extent, TN (fig. 2b), but not sediment (fig. 1b). A 

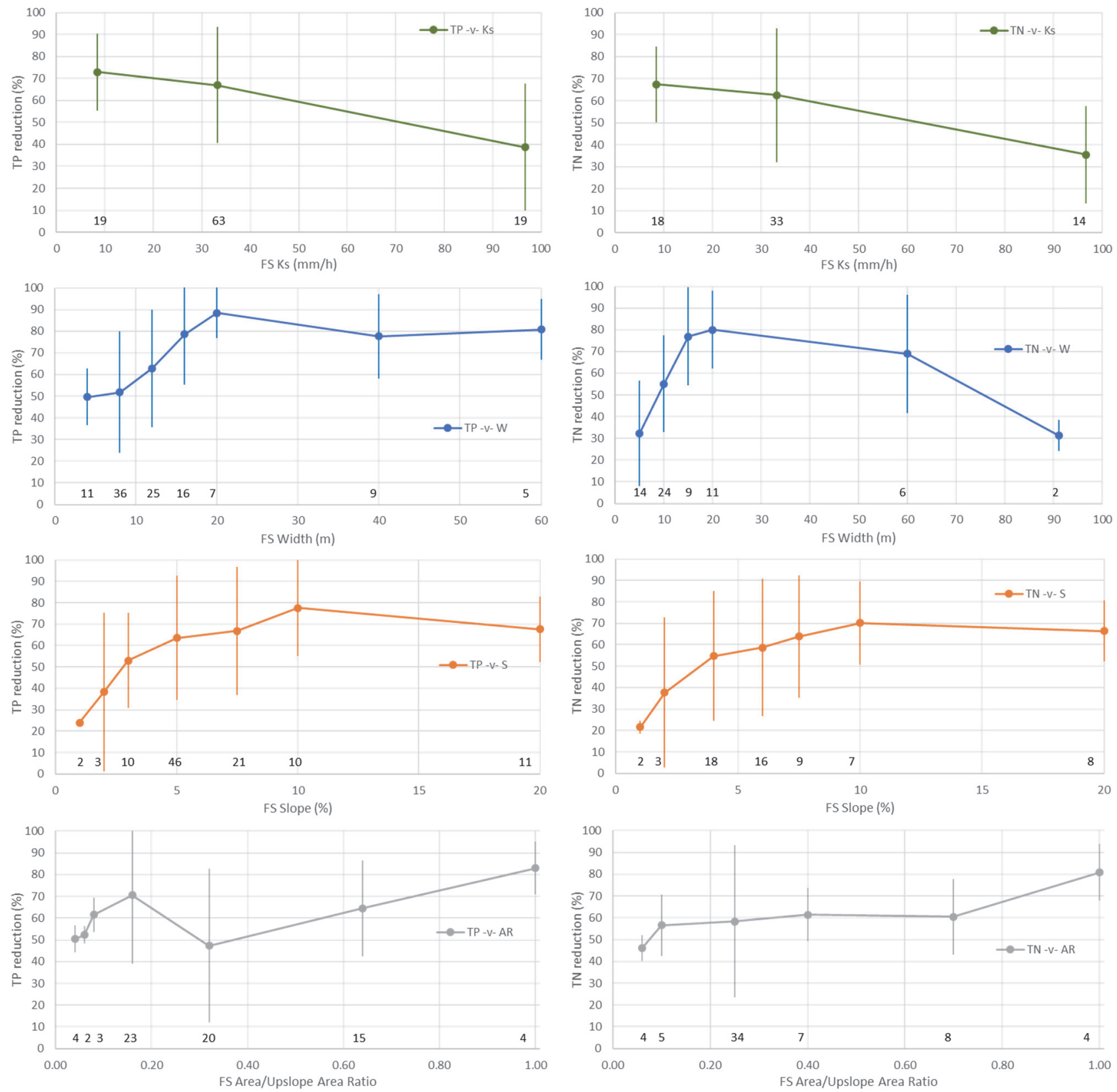

(a)

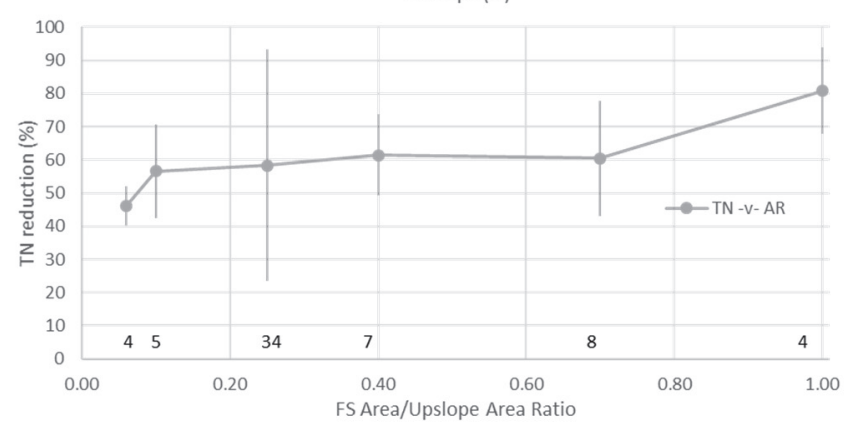

(b)

Figure 2. Effects of filter strip (FS) soil saturated hydraulic conductivity $\left(K_{s}\right)$, width $(W)$, slope $(S)$, and FS area to upslope area ratio (AR) on mass reductions of (a) total phosphorus (TP) and (b) total nitrogen (TN). Data points are means \pm standard deviations of $n$ treatments, with $n$ values shown below.

logarithmic regression was not supported by the expanded data in this article $\left(\mathrm{r}^{2}=0.003, n=150\right.$, using the same data as summarized in table 2).

\section{Area Ratio}

The ratio of FS area to upslope drainage area (AR) influences filter hydrologic and constituent loading and may be useful as a design tool (Dosskey et al., 2005, 2011). Reductions in runoff and sediment were found to increase nonlinearly with AR (Dosskey et al., 2011). The efficiency of FSs with an AR of 0.033 (1:30) were equivalent to those with an AR of 0.067 (1:15) for sediment (Arora et al., 2003) and herbicide (Misra et al., 1996; Arora et al., 2003).
The expanded dataset used in this article was only sufficient to support a significant regression relationship between reduction efficiency and AR for two constituents (table 2): sediment $\left(\mathrm{r}^{2}=0.08, n=161\right)$ as a function of AR $(\mathrm{p}=0.006)$ together with $\mathrm{W}(\mathrm{p}=0.019)$, and ATR $\left(\mathrm{r}^{2}=0.37, n=59\right)$ as a function of AR $(\mathrm{p}=0.049)$ together with $K_{s}(\mathrm{p}=0.0002)$. Visual inspection of the AR reductions in figures 1 through 3 shows no clear trend in response to AR and large variability among treatments and studies.

\section{Slope}

Filter Strip Code 393 (NRCS, 2016) prescribes the FS slope to be less than half that of the upslope source area and no greater than 5\%. Liu et al. (2008) analyzed data from 

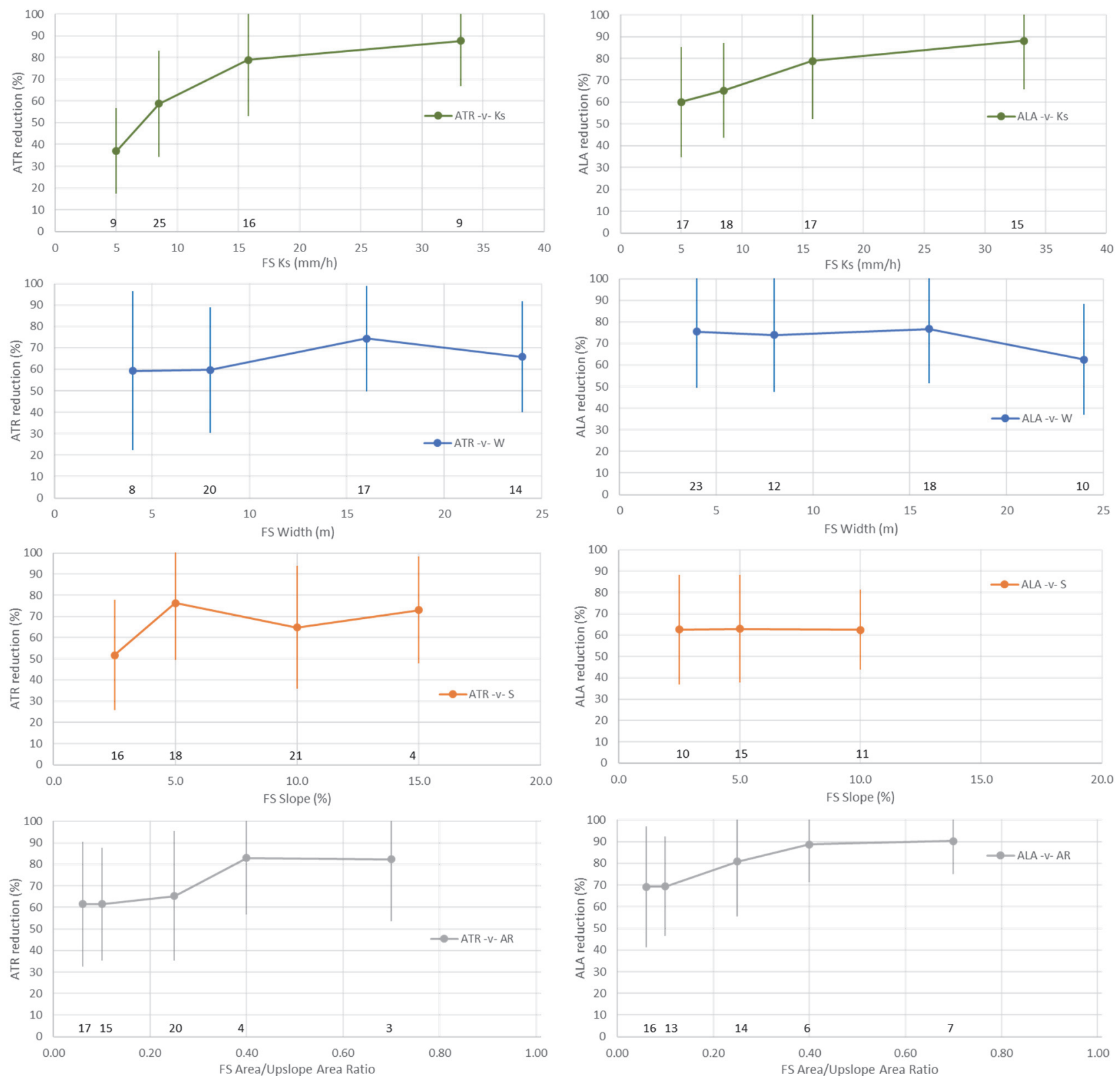

(a)

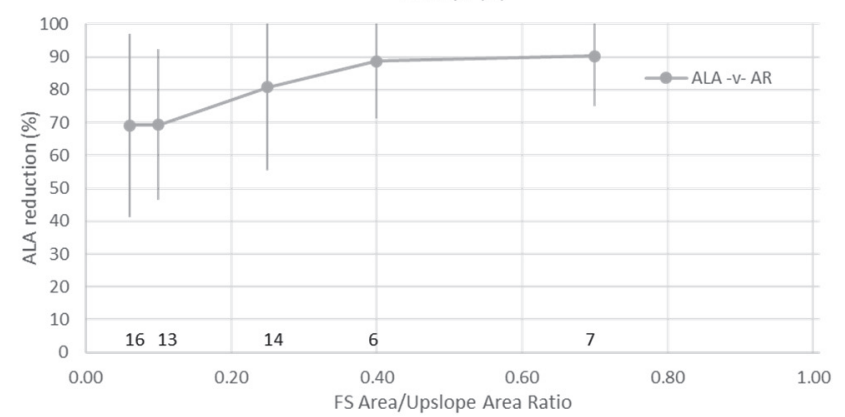

(b)

Figure 3. Effects of filter strip (FS) soil saturated hydraulic conductivity $\left(K_{s}\right)$, width $(W)$, slope (S), and FS area to upslope area ratio (AR) on mass reductions of (a) atrazine (ATR) and (b) alachlor/metolachlor (ALA). Data points are means \pm standard deviations of $n$ treatments, with $n$ values shown below.

about 30 studies and reported that sediment trapping efficiency increased up to about $9 \%$ slope but without physical or theoretical explanation (Fox and Sabbagh, 2009). In an analysis of data from 20 studies, Yuan et al. (2009) reported a similar overall increase in sediment trapping efficiency with slope up to about $7 \%$. However, they also noted that paired comparisons among plots with the same width revealed decreased efficiencies for FSs with greater slope (greater than 5\%). They concluded that the large variability among studies did not support a consistent relationship with slope. Dosskey et al. (2011) used slope and soil texture to adjust FS trapping efficiency in their FS design tool, with greater slope resulting in lower trapping efficiency.
However, results from the present analysis found that slope was not a significant variable in explaining the reduction efficiency for any constituent (table 2). We also found little attenuation in efficiency for slopes up to $10 \%$ or more (figs. 1 to 3), perhaps because distributed "sheet" flows would likely have been maintained in the FSs used in these controlled studies, minimizing one drawback of increasing slope (see the Flow Distribution section).

\section{Inflow Rate and Load}

Abu-Zreig et al. (2003) concluded that inflow rate is a critical secondary factor (to width) in FS efficiency and that adsorption to plant and soil and absorption by plants are possibly important factors for soluble P reduction. Lee et al. 
(2003) noted that, as expected, trapping efficiency decreased as rainfall volume and intensity increased, although the effect of intensity was stronger than that of depth. Van Dijk et al. (1996) found that FS outflow sediment concentration was a function of both $\mathrm{W}$ and inflow concentration. Webster and Shaw (1996) evaluated the impact of a $2 \mathrm{~m}$ wide FS on herbicide runoff from soybean fields. When building best-fit equations to predict herbicide loss, they found that cumulative rainfall and cumulative runoff were significant variables in most of the prediction equations; however, days after herbicide treatment was the most important independent variable, indicating the importance of a short half-life in decreasing runoff losses. Boyd et al. (2003) found that two primary mechanisms (infiltration and sedimentation) interacted with contaminant adsorption to influence filter performance in central Iowa; low to moderately adsorbed pesticides (e.g., ATR, ALA) moved with the runoff water phase and were measurable in tile outflows from beneath the filter, whereas highly adsorbed pesticides (e.g., chlorpyrifos) were more effectively retained by sediment sorption and deposition and were not detected in tile outflows.

Filter strips have been found to be less effective or ineffective in reducing sediment and nutrients in high-intensity, high-volume stormflows ( $>50$ to $100 \mathrm{~mm}$, Daniels and Gilliam, 1996). Dosskey et al. (2011) demonstrated the influence of rainfall amounts on sediment trapping efficiency. They recommended including rainfall intensity in FS design and noted the commonly recommended use of a 10-year, $1 \mathrm{~h}$ storm for conservation practice design (Haan et al., 1994; Larson et al., 1997). Indeed, the average simulated rainfall intensity in the dataset reviewed in this study was $63 \mathrm{~mm} \mathrm{~h}^{-}$ ${ }^{1}(n=17$ studies reported; Douglas-Mankin, 2021), which is about the intensity of a 10-year, $1 \mathrm{~h}$ storm in the central midwestern U.S. (Hershfield, 1961; Huff and Angel, 1992).

\section{Vegetation}

Dosskey et al. (2007) and Parsons et al. (1993) reported that grass and forest vegetation were equally effective as FSs, although riparian plots were more susceptible to channelization (Parsons et al., 1993). Lee et al. (2003) found that switchgrass in FSs was more effective at sediment, $\mathrm{N}$, and $\mathrm{P}$ reduction than native, cool-season grasses. Pilon et al. (2017) compared the sediment losses from rotationally grazed pasture receiving poultry litter with and without a FS and reported that the $15.3 \mathrm{~m} \mathrm{FS}$ treatment experienced more erosion than the rotationally grazed pasture. The authors attributed the increased sediment loss to lack of fertilizer (and therefore reduced vegetation) in the FS, which led to reduced sediment trapping efficiency and possible higher erosion. Van Dijk et al. (1996) found that older (well established), higher-density grass increased runoff retention.

Adsorption to plants, plant litter, and soil, and assimilation by plants and microbes are possible important factors for reduction of soluble P (Lee et al., 2003; Abu-Zreig et al., 2003) and herbicides (Arora et al., 1996; Krutz et al., 2003). Krutz et al. (2003) found that ATR was reduced by both infiltration (67\%) and adsorption to FS grass, grass thatch, and/or soil surface (33\%). Cole et al. (1997) found that mowed grass height and soil aeration did not affect nutrient and pesticide reductions. Patty et al. (1997) found that grass strips sown perpendicular to the slope performed better in reducing pesticide from runoff. Vanrobaeys et al. (2019) found FSs in Canada to be more effective in reducing TP from summer (growing season) runoff events than either fall (senescence period) runoff events or spring (emergence period) snowmelt events.

\section{Sedimentation}

Dillaha et al. (1989) used rainfall simulation to evaluate the impacts of 4.6 and $9.1 \mathrm{~m} \mathrm{FS}$ on sediment and nutrient runoff and noted that much of the sediment reduction occurred in the first few meters of the buffers. When the vegetation in this area became buried, sediment moved downslope to a new depositional zone. This repeating pattern continued until reaching the bottom of the FS (also noted by Neibling and Alberts, 1979; Tollner et al., 1977). They also noted that sediment reduction efficiency decreased in subsequent runs.

Lee et al. (1999) attributed TN and TP reduction mostly to deposition of sediment. Lee et al. (2003) evaluated a 7.1 $\mathrm{m}$ wide switchgrass FS (along with a combination switchgrass and riparian forest buffer) and its efficiency in removing sediment, $\mathrm{N}$, and $\mathrm{P}$ from surface runoff. The authors highlighted the dominance of particle size on buffer efficiency and, not surprisingly, reported the preferential deposition of larger particles earlier in the FS. More than $90 \%$ of sediment in runoff at the end of the buffer was $<50 \mu \mathrm{m}$. Gharabaghi et al. (2006) also found that sediment reduction increased from 2.5 to $20 \mathrm{~m}$ but with greatest efficiency $(90 \%$ of aggregates larger than $40 \mu \mathrm{m}$ diameter) in the first $5 \mathrm{~m}$. Filtration by vegetation (Lee et al., 1999; Gharabaghi et al., 2006) and litter in the buffer (Lee et al., 1999) contributed to sediment reduction. However, FSs long enough to effectively reduce sediment in runoff were inadequate to control fecal bacteria losses (Coyne et al., 1995, 1998).

Muñoz-Carpena et al. (1999) used data from a FS in the North Carolina Piedmont region to evaluate an enhanced FS model and confirmed the importance of correctly simulating FS hydrology to accurately predict sediment trapping efficiency. Their analysis indicated that particle class and grass spacing were most sensitive for the model's sediment component.

\section{Infiltration}

A review of the literature on vegetative treatment area (Koelsch et al., 2006) concluded that a combination of sedimentation and infiltration processes was critical for effective pollutant reductions. Mankin et al. (2007) reinforced the important role of infiltration, which alone could have accounted for $>75 \%$ of sediment reduction, $>90 \%$ of TP reduction, and $>90 \%$ of TN reduction in their field study. Infiltration was attributed as the primary mechanism for reduction for soluble N (Lee et al., 2003) and herbicides (Arora et al., 1996; Michelson et al., 2003; Misra et al., 1996; Popov et al., 2006), as well as fine particles (Lee et al., 2003). High antecedent soil moisture, with less capacity for infiltration, led to little benefit from native prairie FSs (Hernandez-Santana et al., 2013). Patzold et al. (2007) found that the general decreasing trend in herbicide losses from a FS with time was counteracted by increasing pressures from soil sealing, soil 
moisture, and rainfall amount and intensity, all of which affect infiltration. Popov et al. (2006) reported that infiltration was the only mechanism for herbicide reduction during larger run-on events (16 to $80 \mathrm{~cm})$. Although infiltration plays a primary role in reducing the mass of constituents exiting FSs, dilution by rainfall can be the primary factor in concentration reductions of dissolved contaminants (Schmitt et al., 1999).

The modeling results of Muñoz-Carpena et al. (1999) indicated that initial soil water content and vertical saturated hydraulic conductivity were the most sensitive parameters for simulating FS hydrology. Fox and Sabbagh (2009) presented an exponential relationship between sediment reduction efficiency $(\Delta E, \%)$ and runoff reduction/infiltration $(\Delta Q, \%)$ using data from several studies $\left(\mathrm{r}^{2}=0.51\right)$, although they noted potential limitations of such empirical relationships for design:

$$
\Delta E=100[1-\exp (-0.04 \Delta Q)]
$$

\section{Flow Distribution}

Blanco-Canqui et al. (2006) found that FSs receiving concentrated flows were significantly less effective in removing runoff, sediment, and nutrients; adding a switchgrass barrier to pond and disperse flows before entering the FS increased efficiency. Other studies confirmed reduced efficiency from concentrated flows (Daniels and Gilliam, 1996; Dillaha et al., 1986, 1988, 1989; Dosskey et al., 2002; Poletika et al., 2009; Van Dijk et al., 1996). Dillaha et al. (1989) found that plots with concentrated flow appeared to have similar sediment reduction efficiency as uniform flow plots but only because the slopes of the concentrated flow plots were much smaller. In a novel aspect to their study, Dillaha et al. (1989) surveyed actual FSs in Virginia and determined that FSs in hilly regions were ineffective because flow tended to concentrate above the FS. In contrast, FSs in flatter regions were effective because shallow, uniform flow entered the FS. Similar to their earlier studies (Dillaha et al., 1986; Magette et al., 1987), they concluded that accumulation of surface runoff as concentrated flows within fields before reaching the FS was the most common and critical problem limiting filter efficiency. Many of these observations highlighted the importance of proper FS design (e.g., slope, location, width) and maintenance (shaping, removal of deposited sediment) to maximize efficiency. Magette et al. (1987) identified topographic features and vegetation stand quality as critical factors governing channelization.

After completing an extensive field and modeling assessment, Muñoz-Carpena et al. (1999) surmised that reduced overland sheet flow due to lack of filter maintenance could result in poor efficiency. Webber et al. (2010) found significant reductions in runoff, sediment, and $\mathrm{NO}_{3}-\mathrm{N}$ outflows but speculated that the variability in efficiency resulted from the "complex and dynamic soil-water environment" (e.g., surface condition variability caused by seasonal and biological factors; Muñoz-Carpena et al., 1999) and that the concentrated surface flow in the high-relief site significantly reduced FS efficiency.

\section{Filter Strip Age}

Dosskey et al. (2007) found that FS efficiency improved for at least ten growing seasons following establishment. Increased infiltration over the first three growing seasons after establishment accounted for most of the change. HernandezSantana et al. (2013) found increasing runoff reduction over the first three years of their study of perennial FSs. Lee et al. (2003) assumed that FS efficiency would increase over time as the restored grass stand matured and soil quality increased. However, Helmers et al. (2012) noted that the high levels of sediment reduction found during the first several years after establishment in their study might decrease over time; they concluded that longer-term studies were needed to assess temporal effects on efficiency. We also suggest that development of concentrated flow paths, exacerbated by sediment deposition at the upper edge, would also tend to decrease efficiency over time.

\section{Experimental Considerations}

Dillaha et al. (1989) stressed the importance of noting that most FS studies do not duplicate field conditions, which typically have longer slope lengths, larger upland (contributing) areas, and increased likelihood of concentrated flow. These factors may be partially offset by the typical use of intense rainfall events in simulation studies.

Filter strips may be located anywhere along the landscape gradient from riparian zone to hilltop. Most plot studies reviewed herein were placed at landscape positions that were convenient for research but not related (or relatable) to an actual agricultural landscape position. Hillslope position may influence many factors, such as slope, microclimate (including cool-air drainage and wind effects), soil type (texture, morphology, organic content), soil depth, and depth to water table. Landscape position was not explicitly tested in any of the studies compiled for this study but deserves future assessment.

Helmers et al. (2012) studied the effects of prairie grass FS at the footslope (edge of field) and in combination with prairie grass strips within no-till cropland in Iowa, analyzing four years of runoff and sediment loss data. While the upslope strips were presumed to break up the long slope lengths and reduce concentrated flow, they did not significantly reduce sediment concentrations or loads compared to systems with only a footslope FS. The authors concluded that additional sediment reduction above that of the relatively wide FS at the footslope (37 to $78 \mathrm{~m}$ ) was difficult to achieve with within-field strips.

\section{COST ANALYSIS}

Beyond the opportunity costs associated with taking land out of production, other FS costs include site preparation, establishment costs including seed, and management costs, some of which may be annual and some periodic. Tyndall et al. (2013) highlighted an example of a financial model for perennial systems established on cropped land (Tyndall and Grala, 2009) and consistent with USDA Natural Resource Conservation Service cost assessment guidelines (NRCS, 1998) that can be used to estimate costs of FSs. This approach considers all costs associated with FSs and 
discounted using standard discounted cash-flow formulation. The general cost model for a FS is:

$$
P V C=F S^{S P}+F S^{E}+F S^{M}+F S^{O C}
$$

where

$P V C=$ present value of total costs, which can be converted into an equal annualized cost using a capital recovery factor.

$F S^{S P}=$ present value of site preparation costs (includes tilling or otherwise preparing land).

$F S^{E}=$ present value of vegetation establishment, including all seed, actual planting, and other related actions.

$F S^{M}=$ present value of management and maintenance needs, including activities such as mowing and/or burning.

$F S^{O C}=$ present value of annual opportunity costs manifest in either forgone land rent or crop revenue.

Other methods have also been applied to estimate FS costs. Talberth et al. (2015) reported mean total annualized costs (in 2012 dollars) for grass buffers in the Chesapeake Bay watershed to be $\$ 314 \mathrm{ha}^{-1}$ year ${ }^{-1}$, including $\$ 971 \mathrm{ha}^{-1}$ for installation, $\$ 57 \mathrm{ha}^{-1}$ year $^{-1}$ for maintenance, and $\$ 128 \mathrm{ha}^{-1}$ year ${ }^{-1}$ for land rental. Two studies reported FS costs per unit pollutant reduction (table 3). Yuan et al. (2002) presented costs of numerous agricultural BMPs per unit sediment reduction and found amortized costs (5\% interest, 20 years) to average $\$ 10.3 \mathrm{Mg}^{-1}$ with upslope conventional tillage (CT) and $\$ 14.3 \mathrm{Mg}^{-1}$ with upslope no-till (NT); these costs tended to be among the most expensive among the BMPs assessed, which ranged from $\$ 1.70$ to $\$ 13.80 \mathrm{Mg}^{-1}$ (CT) and from $\$ 2.37$ to $\$ 25.90 \mathrm{Mg}^{-1}$ (NT). For FSs used with typical tillage systems, Helmers et al. (2008) found that the cost per unit reduction decreased as constituent reduction efficiency increased: $\$ 2.2$ to $\$ 1.4 \mathrm{Mg}^{-1}$ sediment (corresponding to $40 \%$ to $60 \%$ reduction), $\$ 1.30$ to $\$ 0.88 \mathrm{Mg}^{-1} \mathrm{~N}(30 \%$ to $50 \%$ reduction), and $\$ 3.74$ to $2.20 \mathrm{Mg}^{-1} \mathrm{P}$ (30\% to $50 \%$ reduction), assuming $\$ 334 \mathrm{ha}^{-1}$ land rental cost and $\$ 16.7 \mathrm{ha}^{-1}$ operational cost. Corresponding cost estimates for FS with NT were $\$ 18.6$ to $\$ 12.5 \mathrm{Mg}^{-1}$ sediment, $\$ 5.07$ to $\$ 3.09 \mathrm{Mg}^{-1} \mathrm{~N}$, and $\$ 16.10$ to $\$ 9.70 \mathrm{Mg}^{-1} \mathrm{P}$.

Tyndall et al. (2013) detailed the cost parameters considered in establishing multi-species prairie strips. While the cost categories for various FSs or riparian forest buffers would likely stay the same, the costs associated with each category will vary greatly depending on several factors: how much work is needed to prepare and seed the site; seed cost, which will vary greatly depending on desired vegetation in the FS; and maintenance, which would also vary greatly depending on vegetation and the objectives of the landowner (e.g., more maintenance may be required to achieve a diverse prairie FS than a monoculture system). For Iowa conditions, Tyndall et al. (2013) used cost information adapted from

Table 3. Filter strip cost per unit reduction of sediment, phosphorus, and nitrogen with upslope conventional tillage (CT) or no-till (NT).

\begin{tabular}{ccccc}
\hline Source & $\begin{array}{c}\text { Upslope } \\
\text { Practice }\end{array}$ & $\begin{array}{c}\text { Sediment } \\
\left(\$ \mathrm{Mg}^{-1}\right)\end{array}$ & $\begin{array}{c}\text { Phosphorus } \\
\left(\$ \mathrm{~kg}^{-1}\right)\end{array}$ & $\begin{array}{c}\text { Nitrogen } \\
\left(\$ \mathrm{~kg}^{-1}\right)\end{array}$ \\
\hline Yuan et al. & $\mathrm{CT}$ & 10.3 & - & - \\
$(2002)$ & $\mathrm{NT}$ & 14.3 & - & - \\
\hline Helmers et al. & $\mathrm{CT}$ & 1.4 to 2.2 & 2.20 to 3.74 & 0.88 to 1.30 \\
$(2008)$ & $\mathrm{NT}$ & 12.5 to 18.6 & 9.70 to 16.10 & 3.09 to 5.07 \\
\hline
\end{tabular}

Kling et al. (2007) and estimated FS establishment costs (in 2012 dollars) to be $\$ 321 \mathrm{ha}^{-1}$, contour prairie strips to be $\$ 630 \mathrm{ha}^{-1}$, contour buffer strips to be $<\$ 630 \mathrm{ha}^{-1}$, and riparian forest buffers to be $\$ 1334 \mathrm{ha}^{-1}$. These establishment costs will vary greatly across the U.S. and globally. State and federal incentive programs such as the Conservation Reserve Program or the Environmental Quality Incentives Program may help offset some of the installation, establishment, maintenance, and opportunity costs. In addition, Tyndall et al. (2013) estimated annualized costs of contour prairie strips to range from $\$ 593$ to $\$ 865 \mathrm{ha}^{-1}$ year ${ }^{-1}$.

To evaluate the cost-effectiveness of these practices, the benefits also need to be quantified. Qiu and Dosskey (2012) highlighted multiple environmental benefits that could be considered in evaluating FS cost-effectiveness. They included hydrological sensitivity, soil erodibility, wildlife habitat, and impervious surface. Other factors that could be included include water quality improvements, such as nutrient, pesticide, or pathogenic bacteria reductions. Schulte et al. (2017) found that replacing $10 \%$ of cropland with prairie strips increased biodiversity and ecosystem services with minimal impact on adjacent crop production areas. While these factors may be difficult to quantify monetarily, future research should work to quantify these factors including not only water quality benefits but a broader range of ecosystem services.

The ultimate cost-effectiveness of FSs will be site-dependent in large part due to differences in opportunity costs, establishment costs, management costs, and environmental efficiency. This article has discussed a review of water quality performance; future work should assess other ecosystem service benefits provided by FSs to comprehensively assess the cost:benefit to guide FS decisions on-farm and at policy and programmatic levels.

\section{MONITORING APPROACHES USED AND RECOMMENDATIONS}

The challenges associated with measuring inflows and outflows in edge-of-field FSs have led to minimal data collection on full-scale (or field-scale) systems. Surface runoff entering the FS is rarely distributed uniformly as runoff approaches the edge of field due to topography and flow concentration. In addition, sediment accumulation along the upslope edge of the FS can further redistribute inflows. Thus, samples taken at specific locations along the FS upslope edge may not be proportionally representative of the remainder of the FS, and redistribution over time as sediment accumulates along the leading edge can change inflow patterns. Despite these difficulties, several studies instrumented sections of full-sized systems at the edge of working agricultural fields. We highlight the methods used in these studies as examples for practical application in other research or monitoring studies of full-scale edge-of-field FSs.

Several studies installed some form of flow-splitting device to measure surface flow volumes and collect FS inflow and outflow samples. In monitoring an established $10 \mathrm{~m}$ grass-shrub buffer bordering a crop field in Kansas, Mankin et al. (2007) noted that neither the upslope nor downslope 
edge of the buffer followed a constant elevation contour, which resulted in variable inflow rates and flow patterns along the FS. They established fixed-width plots within the FS using steel-plate borders oriented along the slope and monitored inflows and outflows using a calibrated runoff sampling system (ROSS) that accumulated runoff from a unit width $(1 \mathrm{~m})$, collected flow-weighted subsamples (using a sump and V-shaped splitter), and redistributed remaining flows (Ngandu and Mankin, 2004). This system accommodated both natural and simulated runoff inflows. Sheridan et al. (1999) used a similar approach in a low-slope, multi-zone riparian buffer in Georgia. Pairs of samplers with flow splitters and buried sample collectors (Sheridan et al., 1996) were installed at the interface of each riparian zone to allow estimation of reduction efficiencies. Smith (1987) used another variant in which surface runoff was intercepted by a length of gutter buried perpendicular to flow and subdivided by a sequence of $50 \%$ splits down to a minimum of $1.56 \%$ of the total flow for analysis. This device generated a single flowproportional sample for each runoff event and was applied to measure both channelized and non-channelized flows. Helmers et al. (2005) first characterized FS flow patterns using a detailed survey (1.5 m grid) and dye-tracer mapping and then monitored surface flow using buried $0.3 \mathrm{~m}$ wide samplers (Eisenhauer et al., 2002), three at both upstream and downstream FS edges, to collect event-based water and sediment samples. Helmers et al. (2005) also applied a novel method to collect data on maximum flow depth within the FS by coating pegs with a soluble paste, installing the pegs in a grid within the FS, and measuring the height to which the paste was washed off after an event.

The various flow-splitter methods (Smith, 1987; Sheridan et al., 1996; Eisenhauer et al., 2002; Ngandu and Mankin, 2004) can be installed in existing buffers with minimal disturbance, are simple and low-cost to fabricate from readily available materials, measure event-based inflow and outflow concentrations and loads, and provide moderately accurate and repeatable data. For example, Ngandu and Mankin (2004) demonstrated that ROSS samplers maintained a reasonable quality assurance metric by falling within a $95 \%$ confidence interval of actual applied volumes in $96 \%$ of cases for divider \#3 (12.5\% of total flow) and in $78 \%$ of cases for divider \#6 (1.56\% of total flow). However, for all samplers described, careful installation and attentive maintenance are required, multiple samplers are needed to accurately represent both FS inflow and outflow measurement, and results are highly sensitive to installation position due to uneven flow patterns into and through buffers.

Watershed nutrient budgets can also serve as a practical approach to assess FS efficiency. A replicated watershedscale study in Nebraska (Helmers et al., 2012; Zhou et al., 2014) compared buffer treatment efficiency using H-flume and automated-sampler measurements at the outlet of each treatment watershed ( 0.47 to 3.19 ha area). Using these data, the authors were able to generate annualized loads and, by comparison among replicated treatments and baseline prairie watersheds, annualized estimates of treatment efficiency. In an experimental watershed in Georgia, Lowrance et al. (1984) created net nutrient retention budgets using measured inputs (precipitation + subsurface), outputs (streamflow), and storage (vegetation) for a suite of nutrients over three years. Watershed budget components were quantified using a broad-crested V-notch weir to measure flow at the watershed outlet, flow-integrated stream samples, subsurface flow analysis of upland and alluvial wells along multiple transects, estimates of $\mathrm{N}$ fixation and $\mathrm{N}$ denitrification from soil core incubations, and estimates of above-ground accumulation in biomass by species. The authors documented the nutrient budgets and demonstrated that long-term storage pools and surface runoff inflows contributed to a lack of nutrient budget closure, but they did not present comparable results from non-treatment watersheds, which are needed to develop specific practice recommendations.

Watershed nutrient budget methods require identification or establishment of watersheds with desired treatments, installation of upstream (for non-headwaters watersheds) and downstream flow gauges and water quality samplers (Harmel et al., 2006), an adequate density of meteorological stations within the study watershed, and additional measurements or estimates of nutrient pools and accumulation rates of upland and FS areas within the study watershed. Data from multiple, otherwise similar watersheds are needed to derive treatment efficiency. These methods are minimally invasive, can measure seasonal to annual-scale inflow and outflow concentrations and loads, and can provide moderately accurate data that can be compared to baseline data to derive treatment efficiency.

When conducting FS efficiency studies, we recommend collection and reporting of W, S, AR, $K_{s}$, soil texture, vegetation type, vegetation cover, rainfall intensity, and rainfall amount, in addition to flow and water quality data (DouglasMankin, 2021). Additional measurements that could influence reduction efficiency include FS age, vegetation density (stems per unit area), hyetograph and inflow hydrograph characteristics (timing, peak, duration), antecedent FS conditions (soil moisture, amount and availability of constituents in surface soils and residue for resuspension or desorption), soil and aggregate particle size distributions in the surface layer, concentrations of nutrients in rainfall, and other drainage area characteristics that affect FS loading. New measures are needed to assess flow concentration within the buffer, although such methods will require development.

\section{CONCLUSION}

The present analysis documents filter strip (FS) efficiency for a broad range of contaminants including sediment, nutrients, pesticides, and fecal indicator organisms. As described by others (e.g., Prosser et al., 2020), the present study also showed a large variability in FS efficiency at a given width. Thus, the examination of other factors in the present study (e.g., area ratio, slope, saturated hydraulic conductivity $\left(K_{s}\right)$, runoff intensity) was an important endeavor. Despite considerable variability, several general trends were observed in the data from 74 studies with 294 different treatments and 3,050 replications. Results showed that runoff reduction tended to increase with increasing width up to $15 \mathrm{~m}$ and that sediment reduction was significantly related to area ratio and width (up to $20 \mathrm{~m}$ ). Total $\mathrm{P}$ reduction was 
significantly related to saturated hydraulic conductivity, and total $\mathrm{N}$ reduction was significantly related to saturated hydraulic conductivity and width. Both total $\mathrm{P}$ and total $\mathrm{N}$ reduction tended to increase with increasing width up to $20 \mathrm{~m}$ and with increasing slope up to $10 \%$. Atrazine and alachlor reductions increased with increasing $K_{s}$ up to about $90 \%$ reduction above $K_{s}$ of $33 \mathrm{~mm} \mathrm{~h}^{-1}$ and with increasing FS:upslope area ratio up to about 0.4 .

In contrast, no differences were observed in efficiency results for differing types of FS studies. We had expected efficiencies to show notable differences between field-scale studies with natural rainfall, plot-scale studies with natural rainfall, and rainfall simulation plots. The lack of differences is attributed to the huge variability in efficiency that results from the complex interaction of site conditions, landscape positions, and runoff characteristics.

The present work also summarized the limited information on FS costs and costs of other agricultural conservation practices. With the lack of available studies on this subject, there is a need for comprehensive assessment of FS cost-effectiveness (cost:benefit) across a range of geographic and soil conditions. These assessments should also include other ecosystem-service benefits that can be derived from FS. The present study also makes monitoring recommendations, acknowledging the challenges of implementing field-scale FS studies. This information is critical to guide on-farm and programmatic FS decisions and to increase the scientific understanding of this commonly used agricultural conservation practice.

\section{REFERENCES}

Abu-Zreig, M., Rudra, R. P., Whiteley, H. R., Lalonde, M. N., \& Kaushik, N. K. (2003). Phosphorus removal in vegetated filter strips. J. Environ. Qual., 32(2), 613-619. https://doi.org/10.2134/jeq2003.6130

Arora, K., Mickelson, S. K., \& Baker, J. L. (2003). Effectiveness of vegetated buffer strips in reducing pesticide transport in simulated runoff. Trans. ASAE, 46(3), 635-644.

https://doi.org/10.13031/2013.13599

Arora, K., Mickelson, S. K., Baker, J. L., Tierney, D. P., \& Peters, C. J. (1996). Herbicide retention by vegetative buffer strips from runoff under natural rainfall. Trans. ASAE, 39(6), 2155-2162. https://doi.org/10.13031/2013.27719

Barfield, B. J., Blevins, R. L., Fogle, A. W., E. Madison, C., Inamdar, S., Carey, D. I., \& Evangelou, V. P. (1998). Water quality impacts of natural filter strips in karst areas. Trans. ASAE, 41(2), 371-381. https://doi.org/10.13031/2013.17187

Barling, R. D., \& Moore, I. D. (1994). Role of buffer strips in management of waterway pollution: A review. Environ. Mgmt., 18(4), 543-558. https://doi.org/10.1007/BF02400858

Blanco-Canqui, H., Gantzer, C. J., \& Anderson, S. H. (2006). Performance of grass barriers and filter strips under interrill and concentrated flow. J. Environ. Qual., 35(6), 1969-1974. https://doi.org/10.2134/jeq2006.0073

Blanco-Canqui, H., Gantzer, C. J., Anderson, S. H., Alberts, E. E., \& Thompson, A. L. (2004). Grass barrier and vegetative filter strip effectiveness in reducing runoff, sediment, nitrogen, and phosphorus loss. SSSA J., 68(5), 1670-1678. https://doi.org/10.2136/sssaj2004.1670

Boyd, P. M., L. Baker, J. L., Mickelson, S. K., \& Ahmed, S. I. (2003). Pesticide transport with surface runoff and subsurface drainage through a vegetative filter strip. Trans. ASAE, 46(3), 675-684. https://doi.org/10.13031/2013.13602

Claassen, R., \& Ribaudo, M. (2016). Cost-effective conservation programs for sustaining environmental quality. Choices, 31(3).

Claassen, R., Horowitz, J., Duquette, E., \& Ueda, K. (2014). Additionality in U.S. Agricultural Conservation and Regulatory Offset Programs. ERR-170. Washington, DC: USDA Economic Research Service. https://doi.org/10.2139/ssrn.2502846

Cole, J. T., Baird, J. H., Basta, N. T., Huhnke, R. L., Storm, D. E., Johnson, G. V., ... Cole, J. C. (1997). Influence of buffers on pesticide and nutrient runoff from bermudagrass turf. J. Environ. Qual., 26(6), 1589-1598.

https://doi.org/10.2134/jeq1997.00472425002600060019x

Collins, A. L., Hughes, G., Zhang, Y., \& Whitehead, J. (2009). Mitigating diffuse water pollution from agriculture: riparian buffer strip performance with width. CAB Reviews, 4(39). https://doi.org/10.1079/PAVSNNR20094039

Coyne, M. S., Gilfillen, R. A., Rhodes, R. W., \& Blevins, R. L. (1995). Soil and fecal coliform trapping by grass filter strips during simulated rain. J. Soil Water Cons., 50(4), 405-408. Retrieved from https://www.jswconline.org/content/jswc/50/4/405.full.pdf Coyne, M. S., Gilfillen, R. A., Villalba, A., Zhang, Z., Rhodes, R. W., Dunn, L., \& Blevins, R. L. (1998). Fecal bacteria trapping by grass filter strips during simulated rain. J. Soil Water Cons., 53(2), 140-145.

Daniels, R. B., \& Gilliam, J. W. (1996). Sediment and chemical load reduction by grass and riparian filters. SSSA J., 60(1), 246251. https://doi.org/10.2136/sssaj1996.03615995006000010037x

Dillaha, T. A., Reneau, R. B., Mostaghimi, S., \& Lee, D. (1989). Vegetative filter strips for agricultural nonpoint-source pollution control. Trans. ASAE, 32(2), 513-519. https://doi.org/10.13031/2013.31033

Dillaha, T. A., Sherrard, J. H., \& Lee, D. (1986). Long-term effectiveness and maintenance of vegetative filter strips. Bulletin 153. Blacksburg, VA: Virginia Water Resources Research Center.

Dillaha, T. A., Sherrard, J. H., Lee, D., Mostaghimi, S., \& Shanholtz, V. O. (1988). Evaluation of vegetative filter strips as a best management practice for feed lots. J. Water Pollut. Control Fed., 60, 1231-1238.

Dosskey, M. G., Eisenhauer, D. E., \& Helmers, M. J. (2005). Establishing conservation buffers using precision information. $J$. Soil Water Cons., 60(6), 349-354.

Dosskey, M. G., Helmers, M. J., \& Eisenhauer, D. E. (2011). A design aid for sizing filter strips using buffer area ratio. J. Soil Water Cons., 66(1), 29-39. https://doi.org/10.2489/jswc.66.1.29

Dosskey, M. G., Helmers, M. J., Eisenhauer, D. E., Franti, T. G., \& Hoagland, K. D. (2002). Assessment of concentrated flow through riparian buffers. J. Soil Water Cons., 57(6), 336-343.

Dosskey, M. G., Hoagland, K. D., \& Brandle, J. R. (2007). Change in filter strip performance over ten years. J. Soil Water Cons., 62(1), 21-32.

Douglas-Mankin, K. R. (2021). Supplemental table for "Review of filter strip performance and function for improving water quality from agricultural lands." Trans. ASABE, 64(2). Available at https://doi.org/10.13031/13557833.v2

Eisenhauer, D., Helmers, M., Brothers, J., Dosskey, M., Franti, T., Boldt, A., \& Strahm, B. (2002). An overland flow sampler for use in vegetative filters. ASAE Paper No. 022050. St. Joseph, MI: ASAE. https://doi.org/10.13031/2013.17643

Fox, G. A., \& Sabbagh, G. J. (2009). Comment on "Major factors influencing the efficacy of vegetated buffers on sediment trapping: A review and analysis" by Xingmei Liu, Xuyang Zhang, and Minghua Zhang in the Journal of Environmental 
Quality 2008 37: 1667-1674. J. Environ. Qual., 38(1), 1-3. https://doi.org/10.2134/jeq2009.0001le

Gharabaghi, B., Rudra, R. P., \& Goel, P. K. (2006). Effectiveness of vegetative filter strips in removal of sediments from overland flow. Water Qual. Res. J., 41(3), 275-282. https://doi.org/10.2166/wqrj.2006.031

Haan, C. T., Barfield, B. J., \& Hayes, J. C. (1994). Design hydrology and sedimentology for small catchments. New York, NY: Academic Press.

Harmel, R. D., King, K. W., Haggard, B. E., Wren, D. G., \& Sheridan, J. M. (2006). Practical guidance for discharge and water quality data collection on small watersheds. Trans. ASABE, 49(4), 937-948. https://doi.org/10.13031/2013.21745

Helmers, M. J., Eisenhauer, D. E., Dosskey, M. G., Franti, T. G., Brothers, J. M., \& McCullough, M. C. (2005). Flow pathways and sediment trapping in a field-scale vegetative filter. Trans. ASAE, 48(3), 955-968. https://doi.org/10.13031/2013.18508

Helmers, M. J., Isenhart, T. M., Dosskey, M. G., Dabney, S. M., \& Strock, J. S. (2008). Buffers and vegetative filter strips. Proc. Final Report: Gulf Hypoxia and Local Water Quality Concerns Workshop (pp. 43-58). St. Joseph, MI: ASABE.

Helmers, M. J., Zhou, X., Asbjornsen, H., Kolka, R., Tomer, M. D., \& Cruse, R. M. (2012). Sediment removal by prairie filter strips in row-cropped ephemeral watersheds. J. Environ. Qual., 41(5), 1531-1539. https://doi.org/10.2134/jeq2011.0473

Hernandez-Santana, V., Zhou, X., Helmers, M. J., Asbjornsen, H., Kolka, R., \& Tomer, M. (2013). Native prairie filter strips reduce runoff from hillslopes under annual row-crop systems in Iowa, USA. J. Hydrol., 477, 94-103. https://doi.org/10.1016/j.jhydrol.2012.11.013

Hershfield, D. M. (1961). Rainfall frequency atlas of the United States. Tech. Paper 40. Washington, DC: U.S. Weather Bureau.

Huff, F. A., \& Angel, J. R. (1992). Rainfall frequency atlas of the Midwest. Bulletin 711. Champaign, IL: Illinois State Water Survey.

Kling, C., Robotyagov, S., Ja, M., Feng, H., Parcel, J., Gassman, P., \& Campbell, T. (2007). Conservation practices in Iowa: Historical investments, water quality, and gaps. A report to the Iowa farm bureau and partners. Final Report. Ames, IA: Iowa State University Center for Agricultural and Rural Development.

Knauer, N., \& Mander, U. (1989). Untersuchungen uber die Filterwirkung verschiedner Saum-biotope an Gewassern in Schleswig-Holstein: 1. Mitteilung: Filterung von Stickstoff und Phosphor. Zeitschrift für Kulturtechnick und Landentwicklung, 30, 365-376.

Koelsch, R. K., Lorimor, J. C., \& Mankin, K. R. (2006). Vegetative treatment systems for management of open-lot runoff: Review of literature. Appl. Eng. Agric., 22(1), 141-153. https://doi.org/10.13031/2013.20190

Krutz, L. J., Senseman, S. A., Dozier, M. C., Hoffman, D. W., \& Tierney, D. P. (2003). Infiltration and adsorption of dissolved atrazine and atrazine metabolites in buffalograss filter strips. $J$. Environ. Qual., 32(6), 2319-2324. https://doi.org/10.2134/jeq2003.2319

Krutz, L. J., Senseman, S. A., Zablotowicz, R. M., \& Matocha, M. A. (2005). Reducing herbicide runoff from agricultural fields with vegetative filter strips: A review. Weed Sci., 53(3), 353367. https://doi.org/10.1614/WS-03-079R2

Lafrance, P., Caron, E., \& Bernard, C. (2013). Impact of grass filter strips length on exported dissolved masses of metolachlor, atrazine, and deethylatrazine: A four-season study under natural rain conditions. Soil Use Mgmt., 29(1), 87-97. https://doi.org/10.1111/sum.12016

Larson, W. E., Lindstrom, M. J., \& Schumacher, T. E. (1997). The role of severe storms in soil erosion: A problem needing consideration. J. Soil Water Cons., 52(2), 90-95.
Lee, K. H., Isenhart, T. M., Schultz, R. C., \& Mickelson, S. K. (1999). Nutrient and sediment removal by switchgrass and coolseason grass filter strips in central Iowa, USA. Agrofor. Syst., 44(2), 121-132. https://doi.org/10.1023/A:1006201302242

Lee, K.-H., Isenhart, T. M., \& Schultz, R. C. (2003). Sediment and nutrient removal in an established multi-species riparian buffer. J. Soil Water Cons., 58(1), 1-8.

Lee, P., Smyth, C., \& Boutin, S. (2004). Quantitative review of riparian buffer width guidelines from Canada and the United States. J. Environ. Mgmt., 70(2), 165-180. https://doi.org/10.1016/j.jenvman.2003.11.009

Liu, X., Zhang, X., \& Zhang, M. (2008). Major factors influencing the efficacy of vegetated buffers on sediment trapping: A review and analysis. J. Environ. Qual., 37(5), 1667-1674. https://doi.org/10.2134/jeq2007.0437

Loftus, T. T., \& Kraft, S. E. (2003). Enrolling conservation buffers in the CRP. Land Use Policy, 20(1), 73-84. https://doi.org/10.1016/S0264-8377(02)00046-7

Lowrance, R., Todd, R., Fail Jr., J., Hendrickson Jr., O., Leonard, R., \& Asmussen, L. (1984). Riparian forests as nutrient filters in agricultural watersheds. BioScience, 34(6), 374-377. https://doi.org/10.2307/1309729

Magette, W. L., Brinsfield, R. B., Palmer, R. E., \& Wood, J. D. (1989). Nutrient and sediment removal by vegetated filter strips. Trans. ASAE, 32(2), 663-667. https://doi.org/10.13031/2013.31054

Magette, W. L., Brinsfield, R. B., Palmer, R. E., Wood, J. D., Dillaha, T. A., \& Reneau, R. B. (1987). Vegetated filter strips for agriculture runoff treatment. Report No. CBP/TRS 2/87003314-01. Philadelphia, PA: U.S. Environmental Protection Agency.

Mankin, K. R., Ngandu, D. M., Barden, C. J., Hutchinson, S. L., \& Geyer, W. A. (2007). Grass-shrub riparian buffer removal of sediment, phosphorus, and nitrogen from simulated runoff. JAWRA, 43(5), 1108-1116. https://doi.org/10.1111/j.17521688.2007.00090.x

Mayer, P. M., Reynolds, S. K., McCutcheon, M. D., \& Canfield, T. J. (2005). Riparian buffer width, vegetative cover, and nitrogen removal effectiveness: A review of current science and regulations. EPA/600/R-05/118. Cincinnati, OH: U.S. Environmental Protection Agency.

Mickelson, S. K., Baker, J. L., \& Ahmed, S. I. (2003). Vegetative filter strips for reducing atrazine and sediment runoff transport. J. Soil Water Cons., 58(6), 359-367.

Misra, A. K., Baker, J. L., Mickelson, S. K., \& Shang, H. (1996). Contributing area and concentration effects on herbicide removal by vegetative buffer strips. Trans. ASAE, 39(6), 21052111. https://doi.org/10.13031/2013.27713

Muñoz-Carpena, R., Parsons, J. E., \& Gilliam, J. W. (1999). Modeling hydrology and sediment transport in vegetative filter strips. J. Hydrol., 214(1), 111-129. https://doi.org/10.1016/S0022-1694(98)00272-8

Neibling, W. H., \& Alberts, E. E. (1979). Composition and yield of soil particles transported through sod strips. ASAE Paper No. 792065. St. Joseph, MI: ASAE.

Ngandu, D. M., \& Mankin, K. R. (2004). Runoff sampling system for riparian buffers. Appl. Eng. Agric., 20(5), 593-598. https://doi.org/10.13031/2013.17461

NRCS. (1998). National resource economics handbook, Part 611: Water resources handbook for economics, . Washington, DC: USDA Natural Resources Conservation Service.

NRCS. (2016). Conservation Practice Standard - Filter Strip, Code 393. Washington, DC: USDA Natural Resources Conservation Service.

NRCS. (2017). National handbook of conservation practices Conservation practices, Part 620. Washington, DC: USDA 
Natural Resources Conservation Service. Retrieved from https://directives.sc.egov.usda.gov/viewerFS.aspx?hid=22299

Parsons, J. E., Daniels, R. B., Gilliam, J. W., \& Dillaha, T. A. (1993). Reduction in sediment and chemical load in agricultural field runoff by vegetative filter strips. UNC-WRRI 286. Raleigh, NC: North Carolina State University.

Patty, L., Real, B., \& Joel Gril, J. (1997). The use of grassed buffer strips to remove pesticides, nitrate, and soluble phosphorus compounds from runoff water. Pesticide Sci., 49(3), 243-251. https://doi.org/10.1002/(SICI)10969063(199703)49:3<243::AID-PS510>3.0.CO;2-8

Patzold, S., Klein, C., \& Brummer, G. W. (2007). Runoff transport of herbicides during natural and simulated rainfall and its reduction by vegetated filter strips. Soil Use Mgmt., 23(3), 294305. https://doi.org/10.1111/j.1475-2743.2007.00097.x

Pilon, C., Moore Jr., P. A., Pote, D. H., Pennington, J. H., Martin, J. W., Brauer, D. K., ... Lee, J. (2017). Long-term effects of grazing management and buffer strips on soil erosion from pastures. J. Environ. Qual., 46(2), 364-372. https://doi.org/10.2134/jeq2016.09.0378

Poletika, N. N., Coody, P. N., Fox, G. A., Sabbagh, G. J., Dolder, S. C., \& White, J. (2009). Chlorpyrifos and atrazine removal from runoff by vegetated filter strips: Experiments and predictive modeling. J. Environ. Qual., 38(3), 1042-1052. https://doi.org/10.2134/jeq2008.0404

Popov, V. H., Cornish, P. S., \& Sun, H. (2006). Vegetated biofilters: The relative importance of infiltration and adsorption in reducing loads of water-soluble herbicides in agricultural runoff. Agric. Ecosyst. Environ., 114(2), 351-359. https://doi.org/10.1016/j.agee.2005.11.010

Prosser, R. S., Hoekstra, P. F., Gene, S., Truman, C., White, M., \& Hanson, M. L. (2020). A review of the effectiveness of vegetated buffers to mitigate pesticide and nutrient transport into surface waters from agricultural areas. J. Environ. Mgmt., 261, 110210. https://doi.org/10.1016/j.jenvman.2020.110210

Qiu, Z., \& Dosskey, M. G. (2012). Multiple function benefit: Cost comparison of conservation buffer placement strategies. Landscape Urban Plan., 107(2), 89-99. https://doi.org/10.1016/j.landurbplan.2012.05.001

Reichenberger, S., Sur, R., Kley, C., Sittig, S., \& Multsch, S. (2019). Recalibration and cross-validation of pesticide trapping equations for vegetative filter strips (VFS) using additional experimental data. Sci. Total Environ., 647, 534-550. https://doi.org/10.1016/j.scitotenv.2018.07.429

Saxton, K. E., \& Rawls, W. J. (2006). Soil water characteristic estimates by texture and organic matter for hydrologic solutions. SSSA J., 70(5), 1569-1578. https://doi.org/10.2136/sssaj2005.0117

Schmitt, T. J., Dosskey, M. G., \& Hoagland, K. D. (1999). Filter strip performance and processes for different vegetation, widths, and contaminants. J. Environ. Qual., 28(5), 1479-1489. https://doi.org/10.2134/jeq1999.00472425002800050013x

Schulte, L. A., Niemi, J., Helmers, M. J., Liebman, M., Arbuckle, J. G., James, D. E., ... Witte, C. (2017). Prairie strips improve biodiversity and the delivery of multiple ecosystem services from corn-soybean croplands. Proc. Natl. Acad. Sci., 114(42), 11247-11252. https://doi.org/10.1073/pnas.1620229114

Sheridan, J. M., Lowrance, R. R., \& Henry, H. H. (1996). Surface flow sampler for riparian studies. Appl. Eng. Agric., 12(2), 183188. https://doi.org/10.13031/2013.25638

Sheridan, J. M., Lowrance, R., \& Bosch, D. D. (1999). Management effects on runoff and sediment transport in riparian forest buffers. Trans. ASAE, 42(1), 55-64. https://doi.org/10.13031/2013.13214

Smith, C. M. (1987). Sediment, phosphorus, and nitrogen in channelised surface run-off from a New Zealand pastoral catchment. New Zealand J. Marine Freshwater Res., 21(4), 627639. https://doi.org/10.1080/00288330.1987.9516268

Stutter, M., Kronvang, B., Ó hUallacháin, D., \& Rozemeijer, J. (2019). Current insights into the effectiveness of riparian management, attainment of multiple benefits, and potential technical enhancements. J. Environ. Qual., 48(2), 236-247. https://doi.org/10.2134/jeq2019.01.0020

Talberth, J., Selman, M., Walker, S., \& Gray, E. (2015). Pay for performance: Optimizing public investments in agricultural best management practices in the Chesapeake Bay watershed. Ecol. Econ., 118, 252-261. https://doi.org/10.1016/j.ecolecon.2015.07.033

Tingle, C. H., Shaw, D. R., Boyette, M., \& Murphy, G. P. (1998). Metolachlor and metribuzin losses in runoff as affected by width of vegetative filter strips. Weed Sci., 46(4), 475-479. https://doi.org/10.1017/S0043174500090925

Tollner, E. W., Barfield, B. J., Vachirakornwatana, C., \& Haan, C. T. (1977). Sediment deposition patterns in simulated grass filters. Trans. ASAE, 20(5), 940-944. https://doi.org/10.13031/2013.35679

Tyndall, J. C., \& Grala, R. K. (2009). Financial feasibility of using shelterbelts for swine odor mitigation. Agrofor. Syst., 76(1), 237250. https://doi.org/10.1007/s10457-008-9140-7

Tyndall, J. C., Schulte, L. A., Liebman, M., \& Helmers, M. (2013). Field-level financial assessment of contour prairie strips for enhancement of environmental quality. Environ. Mgmt., 52(3), 736-747. https://doi.org/10.1007/s00267-013-0106-9

Valkama, E., Usva, K., Saarinen, M., \& Uusi-Kämppä, J. (2019). A meta-analysis on nitrogen retention by buffer zones. J. Environ. Qual., 48(2), 270-279. https://doi.org/10.2134/jeq2018.03.0120

Van Dijk, P. M., Kwaad, F. J., \& Klapwijk, M. (1996). Retention of water and sediment by grass strips. Hydrol. Proc., 10(8), 10691080. https://doi.org/10.1002/(SICI)10991085(199608)10:8<1069::AID-HYP412>3.0.CO;2-4

Vanrobaeys, J. A., Owens, P. N., Lobb, D. A., Kieta, K. A., \& Campbell, J. M. (2019). Seasonal efficacy of vegetated filter strips for phosphorus reduction in surface runoff. J. Environ. Qual., 48(4), 880-888. https://doi.org/10.2134/jeq2018.12.0452

Webber, D. F., Mickelson, S. K., Ahmed, S. I., Russell, J. R., Powers, W..., Schultz, R. C., \& Kovar, J. L. (2010). Livestock grazing and vegetative filter strip buffer effects on runoff sediment, nitrate, and phosphorus losses. J. Soil Water Cons., 65(1), 34-41. https://doi.org/10.2489/jswc.65.1.34

Webster, E. P., \& Shaw, D. R. (1996). Impact of vegetative filter strips on herbicide loss in runoff from soybean. Weed Sci., 44(3), 662-671. https://doi.org/10.1017/S0043174500094509

Yuan, Y., Bingner, R. L., \& Locke, M. A. (2009). A review of effectiveness of vegetative buffers on sediment trapping in agricultural areas. Ecohydrology, 2(3), 321-336. https://doi.org/10.1002/eco.82

Yuan, Y., Book, R., Douglas-Mankin, K. R., Christianson, R., Christianson, L., Daggupati, P., ... Messer, T. (2021). Agricultural conservation practices effectiveness reviews. Trans. $A S A B E, 64$ (in review).

Yuan, Y., Dabney, S. M., \& Bingner, R. L. (2002). Costeffectiveness of agricultural BMPs for sediment reduction in the Mississippi Delta. J. Soil Water Cons., 57(5), 259-267.

Zhou, X., Helmers, M. J., Asbjornsen, H., Kolka, R., Tomer, M. D., \& Cruse, R. M. (2014). Nutrient removal by prairie filter strips in agricultural landscapes. J. Soil Water Cons., 69(1), 54-64. https://doi.org/10.2489/jswc.69.1.54 


\section{APPENDIX}

\section{SUPPLEMENTAL REFERENCES}

The following references were used to compile the data in the supplemental table (Douglas-Mankin, 2021).

Abu-Zreig, M., Rudra, R. P., Lalonde, M. N., Whiteley, H. R., \& Kaushik, N. K. (2004). Experimental investigation of runoff reduction and sediment removal by vegetated filter strips. Hydrol. Proc., 18(11), 2029-2037. https://doi.org/10.1002/hyp.1400

Abu-Zreig, M., Rudra, R. P., Whiteley, H. R., Lalonde, M. N., \& Kaushik, N. K. (2003). Phosphorus removal in vegetated filter strips. J. Environ. Qual., 32(2), 613-619. https://doi.org/10.2134/jeq2003.6130

Anderson, K. R., Moore Jr., P. A., Pilon, C., Martin, J. W., Pote, D. H., Owens, P. R., ... DeLaune, P. B. (2019). Long-term effects of grazing management and buffer strips on phosphorus runoff from pastures fertilized with poultry litter. J. Environ. Qual., 49(1), 85-96. https://doi.org/10.1002/jeq2.20010

Arora, K., Mickelson, S. K., \& Baker, J. L. (2003). Effectiveness of vegetated buffer strips in reducing pesticide transport in simulated runoff. Trans. ASAE, 46(3), 635-644. https://doi.org/10.13031/2013.13599

Arora, K., Mickelson, S. K., Baker, J. L., Tierney, D. P., \& Peters, C. J. (1996). Herbicide retention by vegetative buffer strips from runoff under natural rainfall. Trans. ASAE, 39(6), 2155-2162. https://doi.org/10.13031/2013.27719

Barfield, B. J., Blevins, R. L., Fogle, A. W., E. Madison, C., Inamdar, S., Carey, D. I., \& Evangelou, V. P. (1998). Water quality impacts of natural filter strips in karst areas. Trans. ASAE, 41(2), 371-381. https://doi.org/10.13031/2013.17187

Blanco-Canqui, H., Gantzer, C. J., \& Anderson, S. H. (2006). Performance of grass barriers and filter strips under interrill and concentrated flow. J. Environ. Qual., 35(6), 1969-1974. https://doi.org/10.2134/jeq2006.0073

Blanco-Canqui, H., Gantzer, C. J., Anderson, S. H., Alberts, E. E., \& Thompson, A. L. (2004). Grass barrier and vegetative filter strip effectiveness in reducing runoff, sediment, nitrogen, and phosphorus loss. SSSA J., 68(5), 1670-1678. https://doi.org/10.2136/sssaj2004.1670

Borin, M., \& Bigon, E. (2002). Abatement of $\mathrm{NO}_{3}-\mathrm{N}$ concentration in agricultural waters by narrow buffer strips. Environ. Pollut., 117(1), 165-168. https://doi.org/10.1016/S0269-7491(01)00142-7

Borin, M., Bigon, E., Zanin, G., \& Fava, L. (2004). Performance of a narrow buffer strip in abating agricultural pollutants in the shallow subsurface water flux. Environ. Pollut., 131(2), 313321. https://doi.org/10.1016/j.envpol.2004.01.018

Borin, M., Vianello, M., Morari, F., \& Zanin, G. (2005). Effectiveness of buffer strips in removing pollutants in runoff from a cultivated field in northeast Italy. Agric. Ecosyst. Environ., 105(1), 101-114. https://doi.org/10.1016/j.agee.2004.05.011

Boyd, P. M., L. Baker, J. L., Mickelson, S. K., \& Ahmed, S. I. (2003). Pesticide transport with surface runoff and subsurface drainage through a vegetative filter strip. Trans. ASAE, 46(3), 675-684. https://doi.org/10.13031/2013.13602

Chaubey, I., Edwards, D. R., C. Daniel, T. C., Moore Jr., P. A., \& Nichols, D. J. (1994). Effectiveness of vegetative filter strips in retaining surface-applied swine manure constituents. Trans. ASAE, 37(3), 845-850. https://doi.org/10.13031/2013.28149

Chaubey, I., Edwards, D. R., Daniel, T., Moore Jr., P. A., \& Nichols, D. J. (1995). Effectiveness of vegetative filter strips in controlling losses of surface-applied poultry litter constituents.
Trans. ASAE, 38(6), 1687-1692.

https://doi.org/10.13031/2013.27995

Collins, A. L., Hughes, G., Zhang, Y., \& Whitehead, J. (2009). Mitigating diffuse water pollution from agriculture: riparian buffer strip performance with width. CAB Reviews, 4(39). https://doi.org/10.1079/PAVSNNR20094039

Coyne, M. S., Gilfillen, R. A., Rhodes, R. W., \& Blevins, R. L. (1995). Soil and fecal coliform trapping by grass filter strips during simulated rain. J. Soil Water Cons., 50(4), 405-408. Retrieved from https://www.jswconline.org/content/jswc/50/4/405.full.pdf

Coyne, M. S., Gilfillen, R. A., Villalba, A., Zhang, Z., Rhodes, R. W., Dunn, L., \& Blevins, R. L. (1998). Fecal bacteria trapping by grass filter strips during simulated rain. J. Soil Water Cons., 53(2), 140-145.

Daniels, R. B., \& Gilliam, J. W. (1996). Sediment and chemical load reduction by grass and riparian filters. SSSA J., 60(1), 246251 https://doi.org/10.2136/sssaj1996.03615995006000010037x

Dillaha, T. A., Reneau, R. B., Mostaghimi, S., \& Lee, D. (1989). Vegetative filter strips for agricultural nonpoint-source pollution control. Trans. ASAE, 32(2), 513-519. https://doi.org/10.13031/2013.31033

Dillaha, T. A., Sherrard, J. H., Lee, D., Mostaghimi, S., \& Shanholtz, V. O. (1988). Evaluation of vegetative filter strips as a best management practice for feed lots. J. Water Pollut. Control Fed., 60, 1231-1238.

Doyle, R. C., Stanton, G. C., \& Wolf O., C. (1977). Effectiveness of forest and grass buffer filters in improving the water quality of manure polluted runoff. ASAE Paper No. 772501. St. Joseph, MI: ASAE

Ghaffarzadeh, M., Robinson, C. A., \& Cruse, R. M. (1992). Vegetative filter strip effects on sediment deposition from overland flow. In Agronomy abstracts (p. 324). Madison, WI: ASA.

Gharabaghi, B., Rudra, R. P., \& Goel, P. K. (2006). Effectiveness of vegetative filter strips in removal of sediments from overland flow. Water Qual. Res. J., 41(3), 275-282. https://doi.org/10.2166/wqrj.2006.031

Hall, J. K., Hartwig, N. L., \& Hoffman, L. D. (1983). Application mode and alternate cropping effects on atrazine losses from a hillside. J. Environ. Qual., 12(3), 336-340. https://doi.org/10.2134/jeq1983.00472425001200030008x

Hayes, J. C., \& Hairston, J. E. (1983). Modeling the long-term effectiveness of vegetative filter strips on on-site sediment control. ASAE Paper No. 832081. St. Joseph, MI: ASAE.

Helmers, M. J., Eisenhauer, D. E., Dosskey, M. G., Franti, T. G., Brothers, J. M., \& McCullough, M. C. (2005). Flow pathways and sediment trapping in a field-scale vegetative filter. Trans. ASAE, 48(3), 955-968. https://doi.org/10.13031/2013.18508

Helmers, M. J., Zhou, X., Asbjornsen, H., Kolka, R., Tomer, M. D., \& Cruse, R. M. (2012). Sediment removal by prairie filter strips in row-cropped ephemeral watersheds. J. Environ. Qual., 41(5), 1531-1539. https://doi.org/10.2134/jeq2011.0473

Hénault-Ethier, L., Lucotte, M., Smedbol, E., Gomes, M. P., Maccario, S., Laprise, M. E., ... Labrecque, M. (2019). Potential efficiency of grassy or shrub willow buffer strips against nutrient runoff from soybean and corn fields in southern Quebec, Canada. J. Environ. Qual., 48(2), 352-361. https://doi.org/10.2134/jeq2016.10.0391

Knauer, N., \& Mander, U. (1989). Untersuchungen uber die Filterwirkung verschiedner Saum-biotope an Gewassern in Schleswig-Holstein: 1. Mitteilung: Filterung von Stickstoff und Phosphor. Zeitschrift für Kulturtechnick und Landentwicklung, 30, 365-376. 
Kronvang, B., Bechmann, M., Lundekvam, H., Behrendt, H., Rubaek, G. H., Schoumans, O. F., ... Hoffmann, C. C. (2005). Phosphorus losses from agricultural areas in river basins. $J$. Environ. Qual., 34(6), 2129-2144. https://doi.org/10.2134/jeq2004.0439

Kronvang, B., Laubel, A. R., Larsen, S. E., Iversen, H. L., \& Hansen, B. (2000). Soil erosion and sediment delivery through buffer zones in Danish slope units. In The role of erosion and sediment transport in nutrient and contaminant transfer (pp. 6773). IAHS Publication No. 263. Wallingford, UK: International Association of Hydrological Sciences.

Krutz, L. J., Senseman, S. A., Dozier, M. C., Hoffman, D. W., \& Tierney, D. P. (2003). Infiltration and adsorption of dissolved atrazine and atrazine metabolites in buffalograss filter strips. $J$. Environ. Qual., 32(6), 2319-2324. https://doi.org/10.2134/jeq2003.2319

Lafrance, P., Caron, E., \& Bernard, C. (2013). Impact of grass filter strips length on exported dissolved masses of metolachlor, atrazine, and deethylatrazine: A four-season study under natural rain conditions. Soil Use Mgmt., 29(1), 87-97.

https://doi.org/10.1111/sum.12016

Lee, K. H., Isenhart, T. M., Schultz, R. C., \& Mickelson, S. K. (1999). Nutrient and sediment removal by switchgrass and coolseason grass filter strips in central Iowa, USA. Agrofor. Syst., 44(2), 121-132. https://doi.org/10.1023/A:1006201302242

Lee, K.-H., Isenhart, T. M., \& Schultz, R. C. (2003). Sediment and nutrient removal in an established multi-species riparian buffer. J. Soil Water Cons., 58(1), 1-8.

Lee, K.-H., Isenhart, T. M., Schultz, R. C., \& Mickelson, S. K. (2000). Multispecies riparian buffers trap sediment and nutrients during rainfall simulations. J. Environ. Qual., 29(4), 1200-1205. https://doi.org/10.2134/jeq2000.00472425002900040025x

Lim, T. T., Edwards, D. R., Workman, S. R., Larson, B. T., \& Dunn, L. (1998). Vegetated filter strip removal of cattle manure constituents in runoff. Trans. ASAE, 41(5), 1375-1381. https://doi.org/10.13031/2013.17311

Liu, X., Zhang, X., \& Zhang, M. (2008). Major factors influencing the efficacy of vegetated buffers on sediment trapping: A review and analysis. J. Environ. Qual., 37(5), 1667-1674. https://doi.org/10.2134/jeq2007.0437

Lowrance, R., \& Sheridan, J. M. (2005). Surface runoff water quality in a managed three-zone riparian buffer. J. Environ. Qual., 34(5), 1851-1859. https://doi.org/10.2134/jeq2004.0291

Lynch, J. A., Corbett, E. S., \& Mussallem, K. (1985). Best management practices for controlling nonpoint-source pollution on forested watersheds. J. Soil Water Cons., 40(1), 164-167.

Magette, W. L., Brinsfield, R. B., Palmer, R. E., \& Wood, J. D. (1989). Nutrient and sediment removal by vegetated filter strips. Trans. ASAE, 32(2), 663-667. https://doi.org/10.13031/2013.31054

Magette, W. L., Brinsfield, R. B., Palmer, R. E., Wood, J. D., Dillaha, T. A., \& Reneau, R. B. (1987). Vegetated filter strips for agriculture runoff treatment. Report No. CBP/TRS 2/87003314-01. Philadelphia, PA: U.S. Environmental Protection Agency.

Mankin, K. R., Ngandu, D. M., Barden, C. J., Hutchinson, S. L., \& Geyer, W. A. (2007). Grass-shrub riparian buffer removal of sediment, phosphorus, and nitrogen from simulated runoff. JAWRA, 43(5), 1108-1116. https://doi.org/10.1111/j.17521688.2007.00090.x

McKergow, L. A., Weaver, D. M., Prosser, I. P., Grayson, R. B., \& Reed, A. E. (2003). Before and after riparian management: sediment and nutrient exports from a small agricultural catchment, Western Australia. J. Hydrol., 270(3), 253-272. https://doi.org/10.1016/S0022-1694(02)00286-X
Mickelson, S. K., Baker, J. L., \& Ahmed, S. I. (2003). Vegetative filter strips for reducing atrazine and sediment runoff transport. J. Soil Water Cons., 58(6), 359-367.

Misra, A. K., Baker, J. L., Mickelson, S. K., \& Shang, H. (1996). Contributing area and concentration effects on herbicide removal by vegetative buffer strips. Trans. ASAE, 39(6), 21052111. https://doi.org/10.13031/2013.27713

Muñoz-Carpena, R., Parsons, J. E., \& Gilliam, J. W. (1999). Modeling hydrology and sediment transport in vegetative filter strips. J. Hydrol., 214(1), 111-129. https://doi.org/10.1016/S0022-1694(98)00272-8

Parsons, J. E., Daniels R., B., Gilliam J., W., \& Dillaha, T. A. (1991). The effect of vegetation filter strips on sediment and nutrient removal from agricultural runoff. Proc. Conf. Environmentally Sound Agric. (Vol. 1, pp. 324-332).

Parsons, J. E., Daniels, R. B., Gilliam, J. W., \& Dillaha, T. A. (1993). Reduction in sediment and chemical load in agricultural field runoff by vegetative filter strips. UNC-WRRI 286. Raleigh, NC: North Carolina State University.

Parsons, J. E., Daniels, R. D., Gilliam, J. W., \& Dillaha, T. A. (1990). Water quality impacts of vegetative filter strips and riparian areas. ASAE Paper No. 902501. St. Joseph, MI: ASAE.

Parsons, J. E., Gilliam, J. W., Muñoz-Carpena, R., Daniels, R. B., \& Dillaha, T. A. (1994). Nutrient and sediment removal by grass and riparian buffers. Proc. 2nd Conf Environmentally Sound Agric. St. Joseph, MI: ASAE.

Patty, L., Real, B., \& Joel Gril, J. (1997). The use of grassed buffer strips to remove pesticides, nitrate, and soluble phosphorus compounds from runoff water. Pesticide Sci., 49(3), 243-251. https://doi.org/10.1002/(SICI)10969063(199703)49:3<243::AID-PS510>3.0.CO;2-8

Patzold, S., Klein, C., \& Brummer, G. W. (2007). Runoff transport of herbicides during natural and simulated rainfall and its reduction by vegetated filter strips. Soil Use Mgmt., 23(3), 294305. https://doi.org/10.1111/j.1475-2743.2007.00097.x

Pilon, C., Moore Jr., P. A., Pote, D. H., Pennington, J. H., Martin, J. W., Brauer, D. K., ... Lee, J. (2017). Long-term effects of grazing management and buffer strips on soil erosion from pastures. J. Environ. Qual., 46(2), 364-372. https://doi.org/10.2134/jeq2016.09.0378

Pilon, C., Moore Jr., P. A., Pote, D. H., Martin, J. W., Owens, P. R., Ashworth, A. J., ... DeLaune, P. B. (2019). Grazing management and buffer strip impact on nitrogen runoff from pastures fertilized with poultry litter. J. Environ. Qual., 48(2), 297-304. https://doi.org/10.2134/jeq2018.04.0159

Poletika, N. N., Coody, P. N., Fox, G. A., Sabbagh, G. J., Dolder, S. C., \& White, J. (2009). Chlorpyrifos and atrazine removal from runoff by vegetated filter strips: Experiments and predictive modeling. J. Environ. Qual., 38(3), 1042-1052. https://doi.org/10.2134/jeq2008.0404

Popov, V. H., Cornish, P. S., \& Sun, H. (2006). Vegetated biofilters: The relative importance of infiltration and adsorption in reducing loads of water-soluble herbicides in agricultural runoff. Agric. Ecosyst. Environ., 114(2), 351-359. https://doi.org/10.1016/j.agee.2005.11.010

Robinson, C. A., Ghaffarzadeh, M., \& Cruse, R. M. (1996). Vegetative filter strip effects on sediment concentration in cropland runoff. J. Soil Water Cons., 51(3), 227-230.

Schmitt, T. J., Dosskey, M. G., \& Hoagland, K. D. (1999). Filter strip performance and processes for different vegetation, widths, and contaminants. J. Environ. Qual., 28(5), 1479-1489. https://doi.org/10.2134/jeq1999.00472425002800050013x

Sheridan, J. M., Lowrance, R., \& Bosch, D. D. (1999). Management effects on runoff and sediment transport in riparian forest buffers. Trans. ASAE, 42(1), 55-64. https://doi.org/10.13031/2013.13214 
Smith, C. M. (1989). Riparian pasture retirement effects on sediment, phosphorus, and nitrogen in channellised surface runoff from pastures. New Zealand J. Marine Freshwater Res., 23(1), 139-146. https://doi.org/10.1080/00288330.1989.9516349

Srivastava, P., Edwards, D. R., Daniel, T. C., Moore Jr., P. A., \& Costello, T. A. (1996). Performance of vegetative filter strips with varying pollutant source and filter strip lengths. Trans. ASAE, 39(6), 2231-2239. https://doi.org/10.13031/2013.27730

Syversen, N. (1992). Vegetajonssoners effekt pa avrenning frajordbruksarealer-arsrapport 1992. Ås, Norway: Jordforsk.

Thompson, D. B., Loudon, T. L., \& Gerrish, J. B. (1978). Winter spring runoff from manure application plots. ASAE Paper No. 782032. St. Joseph, MI: ASAE.

Tingle, C. H., Shaw, D. R., Boyette, M., \& Murphy, G. P. (1998). Metolachlor and metribuzin losses in runoff as affected by width of vegetative filter strips. Weed Sci., 46(4), 475-479. https://doi.org/10.1017/S0043174500090925

Van Dijk, P. M., Kwaad, F. J., \& Klapwijk, M. (1996). Retention of water and sediment by grass strips. Hydrol. Proc., 10(8), 10691080. https://doi.org/10.1002/(SICI)10991085(199608)10:8<1069::AID-HYP412>3.0.CO;2-4

Vought, L. B. M., Lacoursière, J. O., \& Voelz, N. J. (1991). Streams in the agricultural landscape? Vatten, 47, 321-328.

Vought, L. B. M., Pinay, G., Fuglsang, A., \& Ruffinoni, C. (1995). Structure and function of buffer strips from a water quality perspective in agricultural landscapes. Landscape Urban Plan., 31(1), 323-331. https://doi.org/10.1016/0169-2046(94)01057-F

Watts, D. B., \& Torbert, H. A. (2009). Impact of gypsum applied to grass buffer strips on reducing soluble $\mathrm{P}$ in surface water runoff.
J. Environ. Qual., 38(4), 1511-1517. https://doi.org/10.2134/jeq2008.0378

Webber, D. F., Mickelson, S. K., Ahmed, S. I., Russell, J. R., Powers, W..., Schultz, R. C., \& Kovar, J. L. (2010). Livestock grazing and vegetative filter strip buffer effects on runoff sediment, nitrate, and phosphorus losses. J. Soil Water Cons., 65(1), 34-41. https://doi.org/10.2489/jswc.65.1.34

Webster, E. P., \& Shaw, D. R. (1996). Impact of vegetative filter strips on herbicide loss in runoff from soybean. Weed Sci., 44(3), 662-671. https://doi.org/10.1017/S0043174500094509

Wong, S. L., \& McCuen, R. H. (1982). The design of vegetative buffer strips for runoff and sediment control. College Park, MD: University of Maryland, Department of Civil Engineering.

Young, R. A., Huntrods, T., \& Anderson, W. (1980). Effectiveness of vegetated buffer strips in controlling pollution from feedlot runoff. J. Environ. Qual., 9(3), 483-487. https://doi.org/10.2134/jeq1980.00472425000900030032x

Zhou, X., Helmers, M. J., Asbjornsen, H., Kolka, R., Tomer, M. D., \& Cruse, R. M. (2014). Nutrient removal by prairie filter strips in agricultural landscapes. J. Soil Water Cons., 69(1), 54-64. https://doi.org/10.2489/jswc.69.1.54

Ziegler, A. D., Negishi, J., Sidle, R. C., Preechapanya, P., Sutherland, R. A., Giambelluca, T. W., \& Jaiaree, S. (2006). Reduction of stream sediment concentration by a riparian buffer: Filtering of road runoff in disturbed headwater basins of Montane mainland Southeast Asia. J. Environ. Qual., 35(1), 151-162. https://doi.org/10.2134/jeq2005.0103

Zirschky, J., Crawford, D., Norton, L., Richards, S., \& Deemer, D. (1989). Ammonia removal using overland flow. J. Water Pollut. Control Fed., 61, 1225-1232. 